\title{
Study on Preliminary Phytochemicals and GC-MS Analysis of Justicia adhatoda Leaves Extract
}

\section{R. Malathi*, D. Kaviyarasan, S. Chandrasekar}

Research Department of Biotechnology, Government Arts \& Science College, Perambalur, Tamil Nadu state, India, Pin code - 621107

\begin{abstract}
Several natural products have been implemented as an alternative health care treatment and in discovery of effective modern drugs. A major focus of natural product chemistry has been toward drug design and discovery. Justicia adhatoda is a well-known Indian medicinal plant valued for its pharmacopeia. This plant root, bark, leaf and flower are used to heal several diseases and poisonous bites. The present work was to evaluate the phytochemicals and GC-MS analysis of $J$. adhatoda leaves extracts. The extracts were subjected to qualitative phytochemical screening using standard procedures. The result showed that the phytochemicals present in the extract of J.adhatoda are alkaloids, flavonoids, glycosides, cardiac glycosides, coumarins, hydroxy anthraquinones, tannins, phlobatannins, proteins, xantho protein, steroids and phenols. The GC-MS analysis of acetone extract showed the presence of many secondary metabolites like phytol (0.8\%), 9,12,15-octadecatrienoic acid, $(\mathrm{Z}, \mathrm{Z}, \mathrm{Z})(1.6 \%)$, butane, 2,2-dimethyl (0.21\%), pentane, 2,3,3-trimethyl $(0.22 \%)$, hexathiane $(0.08 \%)$, and benzenesulfonic acid $(0.22 \%)$. The diversity of phytochemical present in the plant suggests that $J$. adhatoda could serve as a source of useful drugs.
\end{abstract}

Keywords: Justicia adhatoda leaves, acetone extract, phytochemicals, GC-MS.

Article Info: Received 08 June 2019; $\quad$ Review Completed 23 July 2019; $\quad$ Accepted 09 Aug 2019; Available online 19 August 2019

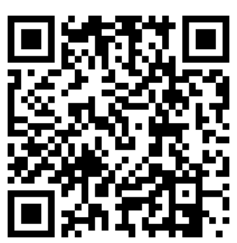

Cite this article as:

Malathi R, Kaviyarasan D, Chandrasekar S, Study on Preliminary Phytochemicals and GC-MS Analysis of Justicia adhatoda Leaves Extract, Journal of Drug Delivery and Therapeutics. 2019; 9(4-s):547-550

http://dx.doi.org/10.22270/jddt.v9i4-s.3380

Dr. R. Malathi, Assistant Professor and Head, Research Department of Biotechnology, Government Arts \& Science College, Perambalur, Tamil Nadu state, India, Pin code - 621107

\section{INTRODUCTION}

Medicinal plants represent a rich source of biologically active components. Plants are used medicinally in different countries of world and as source of many powerful drugs. A wide range of medicinal plant parts were used for extraction of raw drugs as they possess varied medicinal properties [1]. Plants are believed to be important source of new phytochemical with potential therapeutic effects. Traditionally medicinal plants play a greater role in the modern primary oral healthcare system of many countries. Many studies have been reported that the plants are as good as the conventional ones [2-3]. Justicia adhatoda is a wellknown Indian medicinal plant valued for their pharmacopeia. J. adhatoda is a small evergreen herbal plant in the family Acanthaceae. This plant is distributed all over the plains of India and in lower Himalayan ranges. All the parts of $J$. adhatoda has been used for their curative effects from ancient times The phytochemical examination provides vast awareness to pharmacist and helps them in creating diverse medicines to cure different ailments [4]. The present research work was to evaluate the phytochemicals profile of Justicia adhatoda leaves using GC-MS technique.

\section{MATERIALS AND METHODS}

\subsection{Collection and authentication of plant material}

The fresh leaves of Justicia adhatoda plant was collected from the Kurumbalur village, Perambalur district, Tamilnadu, India during the month of October-November 2017. The plant specimen were identified and authenticated by Dr. S. John Britto, Director, The Rapinat Herbarium \& Centre for Molecular Systematics, Saint Joseph's College (Autonomous), Trichy, Tamilnadu (Authentication number: DKA001). The leaves were thoroughly washed in order to remove adhering dust, shade dried under room temperature for 7-8 days. The dried plant leaves were powdered in a mechanical grinder and stored in an air tight container for further use.

\subsection{Extract preparation}

The extract was prepared by adding $20 \mathrm{~g}$ of dried and powdered leaves were separately mounted on the Soxhlet extractor and extracted with $100 \mathrm{ml}$ of different solvents like acetone, chloroform, ethanol, petroleum ether, aqueous, diethyl ether, methanol and ethyl acetate. The extraction 
procedure was carried out until the solvent becomes colorless in the Soxhlet loop. Then extract were concentrated by keeping them at room temperature to allow the solvent to evaporate and the residue was expressed in terms of dry weight, which was used for further analysis. Then the extracts was stored in an air tight container then refrigerated at $4^{\circ} \mathrm{C}$ for further use.

\subsection{Phytochemical analysis}

The phytochemicals analysis of Justicia adhatoda leaves was carried out by the standard method that previously described. The individual extracts were subjected to different qualitative chemical investigation for the establishing profile of the given extracts for their chemical composition. The crude powder was extracted in different solvents are tested for various phytoconstituents present in them by standard procedures [5-6]. They are generally tested for the presence of alkaloids, flavonoids, tannins, phenols, cardiac glycosides, triterpenes, steroids and saponins.

\subsection{Gas Chromatography Mass Spectrum (GC-MS) Analysis}

The phytochemical investigation of acetone extract for GCMS was carried out from Heber Analytical Instrumentation Facility (HAIF), Bishop Heber College, Trichy- 620 017.Using a GC-MS equipment (GC MS QP2020; SHIMADZU) comprising an AOC-20s auto-sampler, an AOC-20i auto-injector and a gas chromatograph(GC-2010) interfaced to a Mass Spectrometer. Experimental conditions of GC-MS system were follows: $\mathrm{SH}-$ Rxi-5Sil-MS capillary standard non-polar column (Dimension: $30.0 \mathrm{~m}$, Diameter: $0.25 \mathrm{~mm}$, Film thickness: $0.25 \mu \mathrm{m}$ is composed of $100 \%$ Dimethyl poly siloxane). An electron ionization energy system with ionization energy of $70 \mathrm{eV}$ was used. Helium gas (99.99\%) was used as the carrier gas at a constant flow rate of $1.20 \mathrm{ml} / \mathrm{min}$ and an injection volume of $5 \mu \mathrm{l}$ was employed (split ratio: 10). Injector temperature $250^{\circ} \mathrm{C}$ : Ion-source temperature $200^{\circ} \mathrm{C}$. The oven temperature was programmed from $50^{\circ} \mathrm{C}$ (isothermal for 2 min.), with an increase of $280^{\circ} \mathrm{C}$ for $10 \mathrm{~min}$. Mass spectra were taken at $70 \mathrm{eV}$; a scan interval of 0.3 seconds with scan range of $50-500 \mathrm{~m} / \mathrm{z}$. Total GC running time was $21 \mathrm{~min}$. The relative percentage amount of each component was calculated by comparing its average peak area to the total areas. Software adopted to handle mass spectra and chromatograms was a shimadzu GC-MS real time analysis.

\subsubsection{Identification of components}

Interpretation of mass spectrum GC-MS was conducted using the database of National Institute Standard and Technique (NIST14) and WILEY8 having more patterns. The spectrum of the unknown component was compared with the spectrum of the known components stored in the NIST14 and WILEY8 library. The Name, Molecular weight, Molecular formula and Structure of the component of the test material were identified.

\section{RESULTS AND DISCUSSION}

The present study was carried out on the plant J.adhatoda leaves to reveal the presence of medicinally active constituents. Phytochemicals studies, being reliable and inexpensive, play an important role in quality control issues of the crude drug samples [7]. The present work was considered to confirm the presence of phytochemicals in different extracts of J.adhatoda.

\subsection{Results of phytochemical analysis of J.adhatoda leaves extracts}

The medicinal value of plant lies in some chemical active substances that produce a definite physiological action on the human body. The most important of these bioactive constituents of plants are alkaloids, tannins, flavonoids and phenolic compounds [8].

The qualitative phytochemical analysis of different extracts of J.adhatoda leaves was showed in Table 1 . The phytochemical analysis results revealed that the presence of alkaloids, flavonoids, glycosides, tannins, proteins, phenols and resins.

The presence of alkaloids was observed in acetone, ethyl acetate, chloroform and water extract in high concentration and petroleum ether extract in small concentration. The flavonoids were detected in very high concentration on acetone extract and high concentration in water extract. The glycosides were present in very high concentration on acetone and water extract. The saponins were present in small concentration in ethanol, water and chloroform extracts. The presence of tannins was observed on acetone, ethanol, water, chloroform, ethyl acetate and diethyl ether extract in very small concentration. The protein was present in high concentration in acetone, ethanol, water and chloroform extracts. The phenols and resins were present in all the extract of J.adhatoda leaves.

Tannins were strong bioactive compounds found in medicinal plant often meet in food artifacts of plant parts that can be used for beneficial reason. Flavanoids have antioxidant properties and used in case of irritation, against microorganisms [9]. Glycosides were used as stimulant in case of cardiac collapse [10]. Sterols that were present in different parts of D.bupleuriodes have been stated to used as antibacterial activities important compound as sex hormones [11]. Saponin that was present in leaves and stem was used to prevent blood lossing and in curing injuries [12].

Based on this results acetone, chloroform and water extracts was showed the presence of different types of phytochemicals when compared to the other extracts. When compared to these three extracts, acetone having the very good phytochemical profile. 
Table 1: Preliminary phytochemical screening of extract of powdered leaves of $\mathrm{J}$. adhatoda

\begin{tabular}{|c|c|c|c|c|c|c|c|c|c|}
\hline \multirow{2}{*}{$\begin{array}{l}\text { S. } \\
\text { No }\end{array}$} & \multirow[t]{2}{*}{ Name of the Compounds } & \multicolumn{5}{|c|}{$\begin{array}{c}\text { Name of the } \\
\text { polar solvents }\end{array}$} & \multicolumn{3}{|c|}{$\begin{array}{l}\text { Name of the non } \\
\text { polar solvents }\end{array}$} \\
\hline & & 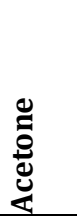 & 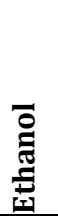 & 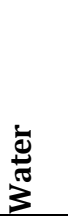 & 司 & 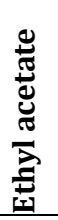 & 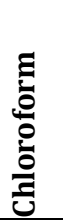 & 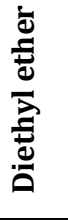 & 苞 \\
\hline 1 & Alkaloids & ++ & ++ & ++ & ++ & ++ & ++ & ++ & + \\
\hline 2 & Flavonoids & +++ & - & +++ & - & + & + & + & - \\
\hline 3 & Carbohydrates & - & - & + & - & - & - & - & - \\
\hline 4 & Glycosides & +++ & + & ++ & - & + & - & - & + \\
\hline 5 & Cardiac glycosides & + & - & + & - & - & - & - & - \\
\hline 6 & Coumarins & + & + & - & + & + & + & - & - \\
\hline 7 & Saponins & - & + & + & - & - & + & - & - \\
\hline 8 & Hydroxyanthraquinones & ++ & - & + & + & + & - & - & - \\
\hline 9 & Tannins & + & + & + & - & + & + & + & - \\
\hline 10 & Phlobatannins & ++ & - & + & + & - & - & - & - \\
\hline 11 & Proteins & ++ & ++ & ++ & - & - & ++ & + & - \\
\hline 12 & Xantho protein & + & - & + & + & + & + & + & - \\
\hline 13 & Amino acids & - & - & - & - & - & - & - & - \\
\hline 14 & Steroids & ++ & - & - & + & - & - & - & - \\
\hline 15 & Terpenoids & - & - & - & - & - & - & - & - \\
\hline 16 & Phenols & ++ & + & + & + & + & ++ & + & + \\
\hline 17 & Resins & + & + & + & + & + & + & + & + \\
\hline 18 & Volatile oil & + & - & - & - & + & + & - & - \\
\hline 19 & Fatty acid & + & - & - & - & - & - & - & + \\
\hline 20 & Emodins & + & - & - & - & - & - & + & - \\
\hline
\end{tabular}

Note: $+\rightarrow$ present in small concentration; $\quad++\rightarrow$ present in moderately high concentration; $+++\rightarrow$ present in very high concentration; - $\rightarrow$ absent

Fig. 1 GC-MS Analysis of Acetone leaves extract of J.adhatoda

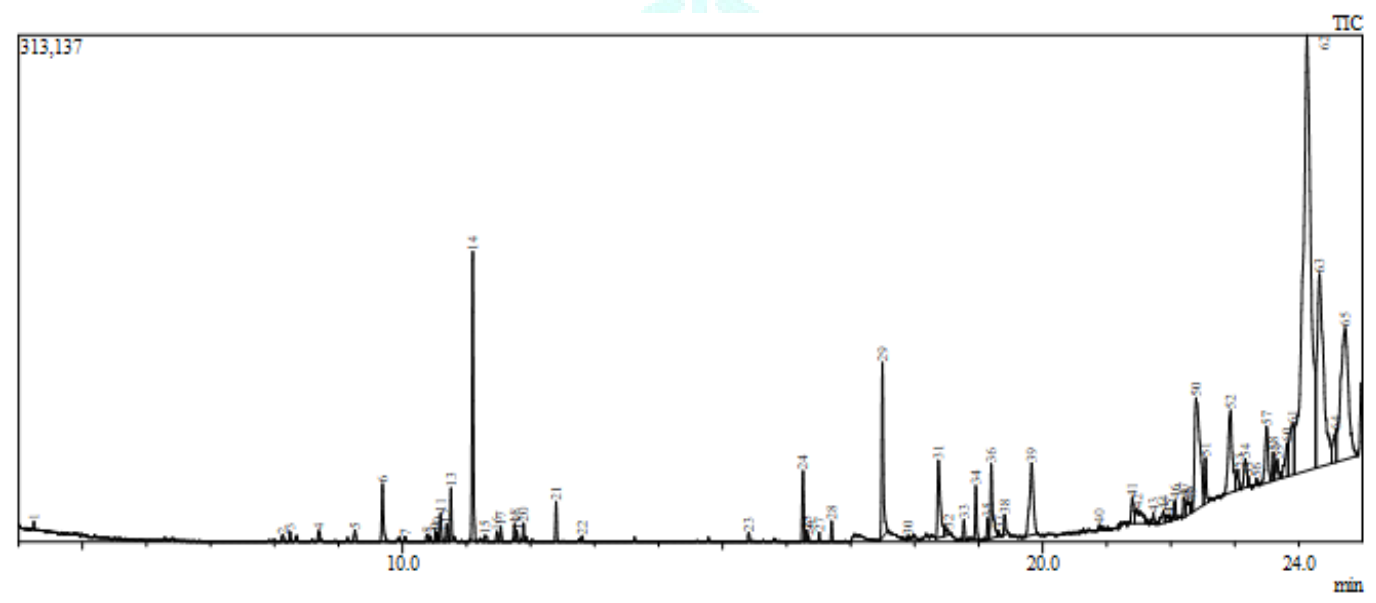

Table-2. Gas chromatography and mass spectrometry analysis of the acetone extract of J.adhatoda

\begin{tabular}{|c|l|c|c|c|c|}
\hline $\begin{array}{c}\text { S. } \\
\text { No }\end{array}$ & \multicolumn{1}{|c|}{ Compound name } & $\begin{array}{c}\text { Retention } \\
\text { Time }\end{array}$ & $\begin{array}{c}\text { Area } \\
\text { (\%) }\end{array}$ & $\begin{array}{c}\text { Molecular } \\
\text { formula }\end{array}$ & $\begin{array}{c}\text { Molecular } \\
\text { weight }\end{array}$ \\
\hline 1. & 3-Pentanol & 8.24 & 0.14 & $\mathrm{C}_{5} \mathrm{H}_{12} \mathrm{O}$ & 88 \\
\hline 2. & Butane, 2,2-dimethyl- & 9.25 & 0.21 & $\mathrm{C}_{6} \mathrm{H}_{14}$ & 86 \\
\hline 3. & Benzenesulfonic acid & 11.75 & 0.22 & $\mathrm{C}_{6} \mathrm{H}_{6} \mathrm{O}_{3} \mathrm{~S}$ & 158 \\
\hline 4. & Cyclohexane, (1-methylethyl)- & 11.79 & 0.13 & $\mathrm{C}_{9} \mathrm{H}_{18}$ & 126 \\
\hline 5. & pentane, 2,3,3-trimethyl- & 11.88 & 0.22 & $\mathrm{C}_{8} \mathrm{H}_{18}$ & 114 \\
\hline 6. & Hexathiane & 12.80 & 0.08 & $\mathrm{~S}_{6}$ & 192 \\
\hline 7. & 1H-Pyrrolo[2,1-b]quinazolin-9-one, 3-hydroxy-2,3-dihydro- & 18.37 & 2.11 & $\mathrm{C}_{11} \mathrm{H}_{10} \mathrm{~N}_{2} \mathrm{O}_{2}$ & 202 \\
\hline 8. & Phytol & 18.95 & 0.8 & $\mathrm{C}_{20} \mathrm{H}_{40} \mathrm{O}$ & 296 \\
\hline 9. & 9,12,15-Octadecatrienoic acid, (Z,Z,Z)- & 19.19 & 1.6 & $\mathrm{C}_{18} \mathrm{H}_{30} \mathrm{O}_{2}$ & 278 \\
\hline 10. & $\begin{array}{l}\text { methanol,[5,7,9-trimethyl-4-(1-propenyl)-3- oxabicyclo [3.3.1] } \\
\text { non-6-en-1-yl]- }\end{array}$ & 21.39 & 0.62 & $\mathrm{C}_{15} \mathrm{H}_{24} \mathrm{O}_{2}$ & 236 \\
\hline 11. & gamma.-Sitosterol & 24.13 & 33.4 & $\mathrm{C}_{29} \mathrm{H}_{50} \mathrm{O}$ & \\
\hline
\end{tabular}




\subsection{Results of GC-MS analysis of Justicia adhatoda leaves acetone extract}

GC-MS is the most excellent technique to identify the functional groups of bioactive constituents of long chain hydrocarbons, alcohols, acids, ester, alkaloids, steroids, amino and nitrogen compound. The present investigation deals with the acetone leaves extract of Justicia adhatoda to analysis the Gas Chromatography - Mass Spectroscopy. The extract is a complex mixture of many constituents totally eleven compounds identified from the plant species Justicia adhatoda. (Table.2) Showed the GC-MS analysis of acetone leaves extract of Justicia adhatoda revealed that the existence of the active compounds like Phytol $(0.8 \%)$, 9,12,15Octadecatrienoic acid, (Z,Z,Z) (1.6\%),1H-Pyrrolo[2,1b]quinazolin-9-one,3-hydroxy-2,3-dihydro (2.11\%), gammaSitosterol (33.4\%), Butane, 2,2-dimethyl (0.21\%), 3-Pentanol $(0.14 \%)$, Benzenesulfonic acid $(0.22 \%)$, Cyclohexane, (1methylethyl) (0.13\%), pentane, 2,3,3-trimethyl (0.22\%), Hexathiane $\quad(0.08 \%)$, methanol,[5,7,9-trimethyl-4-(1propenyl)-3-oxabicyclo[3.3.1]non-6-en-1-yl] (0.62\%) were present. The compounds are identified with their retention time, Molecular formula, Molecular weight and concentration (percentage of peak area). GC-MS analysis (Fig 1) of the acetone leaves extract of Justicia adhatoda showed the presence of 11 major peaks and the components corresponding to the peaks were determined.

The acetone leaves extract of Justicia adhatoda already reported that it has a very good antioxidant activity. Phytol is one of the active compound are used as cancer preventive. The presence of phytol compounds attributes to the antimicrobial, anti-inflammatory and anticancer properties [13,14]. The sterols like gamma Sitosterol and stigmasterol were demonstrated to inhibit viper venom induced lethality, neurotoxicity and hemorrhage[15].

Based on the above findings of the present study, acetone extract of Justicia adhatoda has variety of phytochemicals and it was clear that this plant can be used as a source of novel bioactive constituents.

\section{4.) CONCLUSION}

The phytochemical studies and GC-MS analysis of Justicia adhatoda leaves acetone extract revealed that this plant have a wide variety of medically important phytochemicals. The further research in this plant may help in determining the therapeutic potential of Justicia adhatoda may leads to the development of novel drug.

\section{5.) REFERENCES}

[1] Srivastava J, Lambert and Vietmeyer V. Medicinal Plants: An expanding role in development,World Bank Technical Paper, 2006; . No. 320.

[2] Weijden VD, Timmer CJ, Timmerman MF, Reijerse E, Mantel MS and Velder U Velden. The effect of herbal extracts in an experimental mouth rinse on established plague and gingivitis, Journal of Clinical Periodontal,1998;v. 25, pp. 399-403.

[3] Mullally BH, James JA, Coulter WA and Linden GJ, The efficacy of herbal based tooth paste and control of plague and gingivitis, Journal of Clinical Periodontal, 1995; v. 22, pp. 686-689.

[4] Soobrattee MA, Neergheen VS, Luximon-Ramma A, Aruoma OI, Bahorun T. Phenolics as potential antioxidant therapeutic agents: Mechanism and 324 actions. Mut Res 2013; 579: 200213.

[5] Sofowara A. Medicinal Plants and Traditional Medicinal in Africa Screening Plants for Bioactive Agents. New York: John Wiley, 1993; 134-156.

[6] Raman N. Phytochemical technique. NewDehli: New Indian Publishing Agencies, 2006.

[7] Bigoniya P, Singh CS, Srivastava B. Pharmacognostical and physico-chemical standardization of Syzigium cumini and Azadirachta indica seed. Asian Pac J Trop Biomed, 2012; S290-5.

[8] Edeogal HO, Okwu DE, Mbaebie BO. Phytochemical constituents of some Nigerian medicinal plants. Afr J Biotech, 2005; 4: 685688.

[9] Barakat MZ, Shahab SK, Darwin N, Zahemy EI. Determination of ascorbic acid from plants. Annal Biochem, 1993; 53: 225-245.

[10] Trease GE, Evans WC. Pharmacology. Edition 11. London: Braillieriere Tindall Ltd, 1998; p. 60-75.

[11] Okwu DE. Evaluation of chemical composition of medicinal plants belonging to Euphorbiaceae. Pak VetJ, 2001; 14: 160-162

[12] Okwu DE, Josiah C. Evaluation of the chemical composition of two Nigerian medicinal plants. Afri J Biotech, 2006; 5: 357-361.

[13] Cho, K.H., Hong, J.H., and Lee, K.T., 2010. Monoacylglycerol (MAG)-oleic acid has stronger antioxidant, anti-atherosclerotic, and protein glycation inhibitory activities than MAG-palmitic acid. J Med Food; 13(1):99-107.

[14] Munakata, K., 1983. Nematocidal natural products. In: D.L Whitehead and W.S Bowers (eds.), Natural Products for Innovative Pest Management, Oxford: Pergamon; pp. 299-310.

[15] Gomes A, Archita S, Ipshita C, Chakravarty AK, Viper and cobra venom neutralization by _-sitosterol and stigmasterol isolated from the root extract of Pluchea indica Less. (Asteraceae), Phytomedicine 14 (2007) 637-643. 